\title{
Startup Founders: You Can't Get Back Family Time
}

\author{
Catherine Buday (EIX) \\ Steve Blank (Stanford University)
}

KEYWORDS: Entrepreneurship, Leadership, Startups.

Steve Blank has had a celebrated career as serial entrepreneur and founder of the Lean Startup movement, which for the first time gave startups a methodology for success. Best known as the Father of Modern Entrepreneurship, in January Steve received the Lifetime Award for Entrepreneurial Excellence from the U.S. Association for Small Business and Entrepreneurship for the impact his work has had on entrepreneurship and entrepreneurial education.

But entrepreneurship has a downside that few successful founders want to discuss: it can be very tough on marriages and family life. In fact, more than half of the top 10 most expensive divorces (https://www.businessinsider.com/most-expensivedivorce-settlements-2018-1) involved marriages of famous entrepreneurs.

In his well-read blog(https://steveblank.com/), Steve has been frank about discussing the (https://steveblank.com/2009/06/15/lies-entrepreneurstell-themselves/) cost of his success to his relationships (https://steveblank.com/2009/06/15/lies-entrepreneurstell-themselves/) . In this interview with EIX's Cathy Buday, he discusses how launching a startup can be challenging to family life.

\section{Cathy Buday}

What are the worst human costs that you've observed among entrepreneurs who have launched successful startups?

\section{Steve Blank}

When I was a young entrepreneur I had some great role models at work, and one of them became a mentor. He taught me some enormous lessons, and showed me how to think like an entrepreneur. But years later, I realized that he was awesome only at work and had feet of clay when it came to his family life. His kids grew up, and I could see they hated their dad because he was never home.

\begin{abstract}
What I admired him for was his dedication to work, but only later did I see the cost and damage, and realize that he wasn't alone. There were a lot of people who were giving it all to their work, and I was cheering them on, but they had another life that they had kind of abandoned.
\end{abstract}

That same unrelenting focus on work cost me my first marriage. Luckily my children were born later in my life, when I realized that their growing years are a time you can't get back. It's not time you can make up. And you lie to yourself thinking you can. Many hard-charging entrepreneurs think it will be OK if they give their families an occasional terrific weekend or take a lot of long vacations. But what's really important is putting the kids to bed at night, having dinners with them, reading them stories or taking them places. These formative years are times that you can never get back. I think that is the greatest damage that entrepreneurs do, when they don't realize that.

\section{Cathy Buday}

In your blog you wrote eloquently about how your first marriage broke up (https://steveblank.com/2009/06/15/lies-entrepreneurstell-themselves/) because you were so focused on your work. A lot of young people are dreaming of starting their own company. Maybe they haven't gotten any financing yet, and they're just funding it themselves or with help from family and friends. Is it possible for them to do the work that has to be done to get that investor financing or take the company public -- and still be a good parent, a good son or daughter, or a good friend?

\section{Steve Blank}

No. I'll say no, and then I'll just point out that there are no absolutes and they could be the exception. Starting a company, and by that I mean a startup that wants to scale, is a violent act of aggression that takes extraordinary amounts of time and energy.

It's best done before you have commitments you're not 
going to regret missing. I say that to the founders; early employees can make a choice. The founders have no choice, at least if they want to succeed. That is a conundrum of capitalism. There is nothing that says you have to be totally focused on your startup, but l'd sure like to be your competitor if you decide to work 9-5 and I'm working 9-9; I'll kick your ass from here to Sunday. And l've done that. But the costs are really high.

So when people talk about work-life balance, those are people who've never actually founded a company. I'm not suggesting this is right, I'm just suggesting we ought to be honest about the emotional and family costs. That is the part that we get wrong.

\section{Cathy Buday}

I've heard that an acquaintance of yours bragged recently about how he had dinner with his kids twice over the past two weeks, but it turned out it was actually a Skype call to his family while they were eating.

\section{Steve Blank}

Those are the types of people who are making tradeoffs without realizing the damage they cause. You would never do that if you had 20 years of hindsight. No one would purposely be that cruel. The problem is, we don't get a parenting manual, and new parents learn by doing and often don't have the wisdom of experience. And if you're at a startup, the last people on earth to give you advice about work-life balance are the people invested in you; they want no balance at all. They want $900 \%$ of your time, and you will give it to them because founding a startup is like a drug. You wouldn't work this hard if it wasn't kind of fun and enjoyable and if it didn't create an endorphin.

Raising kids and a family is messy and it's emotional. And, gee, work can be satisfying and every day you move something forward. Watching your kids grow up is a slower process. In the span that your kid has gone from 1-5 years old, you can go public. So you kind of say, well I'll get back to that later. But that later is gone.

\section{Cathy Buday}

What advice would you give to your 20-something self if you were just getting out of college or grad school today and contemplating your first startup?

\section{Steve Blank}

Don't have kids.

\section{Cathy Buday}

But you did have kids!

\section{Steve Blank}

I didn't for the first 15 years of my career as an entrepreneur; I waited until my late 30s. I wish I could tell you it was planned, but my first marriage didn't work out because I was working so hard.

\section{Cathy Buday}

By the time you had children you were at the point where you had launched a few companies. Didn't you achieve a position where you finally could have some flexibility in how you lived your life?

\section{Steve Blank}

Well it was very interesting. I started to realize that when I was working for someone else I would get on a plane at the drop of the hat, and this was pre-kids, fly across the country and exhaust myself. Yet when I was CEO and it was my startup I was being judicious about what I needed to do because I had kids and wanted to see their plays and go to their school stuff. That actually turned out to be a handicap at work, but I have no regrets.

Commerce has no rules for competition in the United States. There is very little social safety net. There is nothing baked into capitalism about family if you think about it.

\section{Cathy Buday}

You've said before that young people graduating from entrepreneurship programs and contemplating a startup often have plenty of data but no wisdom. And you've actually suggested that they follow somebody around so that they know what they're getting into, both on the career and personal fronts.

\section{Steve Blank}

It depends on whom you follow around. I've met at least 20 dumb old people, meaning not that they're stupid but just that they have learned nothing. I'm not saying that a 20-year-old can't be wise, or that every 65-year-old is the font of wisdom, but everybody tends to extrapolate from their own experience. In my case, I was able to watch patterns of my mentors and coworkers over time, and learn from that. Some people don't.

Both young and old entrepreneurs will make mistakes. And what's really interesting is today, in the land of 
infinite capital for startups, your investors will help you repair any damage you make from making stupid decisions, although that is not always the case. You can get multiple shots at the same goal. But nobody will bail you out from the mistakes you make in your personal life, with your marriage or your kids.

\section{Cathy Buday}

How do you make it work now, with your wife and children?

\section{Steve Blank}

It took me four companies and many years to finally get to the point where I could afford to have some family life. Luckily my children came along when I was older and could take some time to be with them. Still, my wife and I had to come to an agreement that raising them could not be 50-50. But we did set some ground rules (https://steveblank.com/2009/06/18/epitaph-for-an-

entrepreneur/) - for example, we would have dinner as a family most nights and then I would put them to bed before working for several more hours. The process will be different for every startup founder and every family, and it helps if you've amassed enough stature and money to do things your own way. My wife worked in the technology industry and understood what it demanded, so that helped too.

When I was younger I lived to work, but over time I realized that working 24/7 wasn't something I wanted to do forever. With this wisdom came the opportunity to nurture a great family, and I feel fortunate.

\section{More From Steve Blank}

Entrepreneurship's Moral Minefields: A Conversation with Steve Blank (https://eiexchange.com/content/382-entrepreneurships -moral-minefields-a-conversatio?search=Entrepreneurs hips\%20Moral\%20minefields) 